\title{
Yerel Yönetimler ve Bütçe İlişkisine Yönelik Akademik Çalışmaların Bibliyometrik Analizi
}

\author{
A Bibliometric Analysis of Academic Studies on Local Governments and \\ Budget Relationship
}

Hülya AĞCASULU ${ }^{1}$, İsmail Sadık YAVUZ²

\begin{abstract}
Öz
Amaç: $\mathrm{Bu}$ araştırmanın amacı, yerel yönetimler ve bütçe ilişkisini inceleyen çalışmaların ortak noktalarını bulmak ve literatürün yoğunlaştığı alanları tespit etmektir.

Tasarım/Yöntem: Araştırmada Web of Science servisinin çekirdek kataloğundan elde edilen 1980-2021 dönemine ait yerel yönetimlerbütçe ilişkisine dair 6535 makale VOSviewer yazılımı kullanılarak bibliyometrik ağ analizi ile haritalanmıştır.

Bulgular: Analizler sonucunda; ilgili literatürün Amerika Birleşik Devletleri adresli kurumlar ve yazarlar tarafından şekillendiği; Çin'in geçiş ekonomisi ile ilgili çalışmaların da sayıca fazla olduğu, çalışmaların çoğunlukla ekonomi (2159 çalışma) ve kamu yönetimi (2139 çalışma) alanlarında yoğunlaştığı ve 2004 sonrasında çalışma sayısının üstel bir fonksiyon şeklinde arttığı sonuçlarına ulaşılmıştır. Sınırlılıklar: Çalışmada kullanılan veri tabanlarının sınırlandırılması 7086 makalenin outlier olarak dışlanması ile sonuçlanmıştır. Outlier parametreleri değiştirilerek interdisipliner karakteristiği artırılmış bir çalışmanın yapılaması mümkün k1lacaktır.

Özgünlük/Değer: Çeşitli alanlarda bibliyometrik analizler kullanılmasına rağmen kamu yönetimi-maliye alanlarını birleştiren, yerel yönetimler-bütçe ilişkisini inceleyen interdisipliner ve alanında öncü bir çalışma olması araştırmanın özgün değeridir.
\end{abstract}

Anahtar Kelimeler: Kamu Yönetimi, Maliye, Bibliyometrik Analiz, VOSviewer

\begin{abstract}
Purpose: The purpose of this research is to determine the common points and areas of focus points of paper in which examining the relationship between local governments and budget.

Design/Methodology: 6535 articles on local government-budget relations for the period 1980-2021, obtained from the core catalog of the Web of Science Service, were mapped using bibliometric network analysis using VOSviewer software.

Findings: As a result of the analysis; it was concluded that the relevant literature was shaped by the institutions and authors from the United States of America, there are multiple research on transition economy of China, the research is mostly focused on economics (2159 studies), and public administration (2139 studies), and the number of studies is exponentially increased after 2004.

Limitations: The limitation of the databases used in the study resulted in the exclusion of 7086 articles as outlier. Changing the outlier parameters will make it possible to make a study with increased interdisciplinary characteristics.
\end{abstract}

Originality/Value: Bibliometric analysis is used in many areas. However, this paper examines the relationship between local governments and the budget by uniting the fields of public administration and finance, being an interdisciplinary and pioneering work in its field are the basic building blocks that constitute its original value.

Keywords: Public Administration, Public Finance, Bibliometric Analysis, VOSviewer

\footnotetext{
${ }^{1}$ Dr. Öğr. Üyesi, Süleyman Demirel Üniversitesi, İktisadi ve İdari Bilimler Fakültesi, Siyaset Bilimi ve Kamu Yönetimi Bölümü, hulyatek@ sdu.edu.tr, ORCID: 0000-0003-3939-904X

2 Dr. Öğr. Üyesi, Süleyman Demirel Üniversitesi, İktisadi ve İdari Bilimler Fakültesi, Maliye Bölümü, ismailyavuz@sdu.edu.tr, ORCID: 0000-0002-0070-1363
} 


\section{GİRİş}

21. yüzyılda toplumlar, sürekli ve hızlı değişen koşullara adapte olmak ve devletler de karmaşı sorunlara çok yönlü yaklaşımlarla çözüm bulmak zorundadır. Günümüzde farklı akademik disiplinlerin birbirleriyle etkileşim halinde oldukları ve toplumsal sorunlara bütüncül bir bakış açısı geliştirmeye çalıştıkları bir gerçektir. Bu durum multidisipliner çalışma ve araştırmaların önem kazanıp yaygınlaşmasına katkıda bulunmaktadır.

Yerel yönetimleri, yetkili oldukları coğrafi alandaki çeşitli kamu hizmetlerini sunma sorumluluğu ile donatılan ve bu amaçla idari ve mali özerklik tanınan kamu tüzel kişilikleri olarak tanımlamak mümkündür. Yerel yönetimler, kamu yönetiminin vazgeçilmez birimleridir. Bu birimler yerel halkın günlük ihtiyaçlarını karşılamak amacıyla, hijyen, kanalizasyon, çöp toplama, ulaşım gibi hizmetleri sunarlar ve aynı zamanda ülke kalkınması açısından önemli olan eğitim, sağlık ve altyapı gibi görevleri de yerine getirirler (Ulusoy \& Akdemir, 2009). Ülkemizde belediye, il özel idaresi ve köyler olarak sınıflandırılan yerel yönetimler sorumluluk alanlarındaki hizmetleri yerine getirirken beşeri ve mali kaynakları kullanır ve gerekli ekipman ve donanımlardan yararlanırlar (Arıkboğa, 2008). Bu birimlerin görevlerini hakkıyla yerine getirebilmeleri için ise yeterli bütçeye sahip olmaları gerekmektedir. Bunun yanı sıra kamu kurumlarının performans değerlendirmelerinde bütçeyi etkin ve etkili kullanmaları da bir ölçüttür (Yenice, 2006).

Yerel yönetimler ve kentleşme 20. yüzyılın başından itibaren güçlenmeye başlamıştır. Özellikle küreselleşme, yönetişim ve neo-liberal politikaların da yerel yönetimlerin öneminin artmasında rolü bulunmaktadır. Bu yükseliş eğilimi aynı zamanda yetkilerin ve yetki alanlarının genişlemesi, kamu hizmetlerinin çeşitlenip kapsamının arttırılması anlamına da gelmektedir. Artan yetki ve yetki alanları ile çeşitlenen hizmetlere cevap verebilmesi ise mali imkanlara bağlı olduğu için yerel yönetimler ve bütçe arasındaki sıkı ilişki her geçen gün artmıştır. Ayrıca son yıllarda, hizmette yerellik ilkesi, mali özerklik, görevlerle orantılı kaynaklar, kamu mali yönetimi ve hesap verebilirlik gibi kavramlar da yerel yönetimler ve bütçe ile ilişkili olarak sıkça kullanılmaktadır (Eryılmaz, 2019).

Son yıllarda kamusal hizmetler ve gelir kaynaklarının desantralizasyonu, hizmette yerellik ilkesi, yerel yönetimlere daha fazla özerklik verilmesi, kamu maliyetlerinin azaltılması ve vesayet yetkisini azaltma yönünde yaşanan gelişmeler, dünyanın birçok ülkesinde merkezi yönetimle yerel yönetimler arasındaki gelir bölüşümünü etkilemiş, birçok devletinde anayasa ve reform çalışmalarıyla bu yönde önemli değişimler yaşamasına sebep olmuştur (Arıkboğa, 2008). Yaşanan gelişme ve reformlar da yerel yönetimler ve mali yönetim konularındaki akademik çalışmaların artmasına neden olmuştur.

Günümüzde akademik çalışmaların nicelik olarak hacmi artmıştır. Dolayısıyla herhangi bir alandaki yayınlara ilişkin anlamlı bilgilerin elde edilmesi, yayın sayılarının artmasıyla orantılı olarak giderek zorlaşmıştır. Bu zorluklar bibliyometrik analizler sayesinde aşılabilmektedir. Bibliyomretik analizler $^{1}$ veya bilimsel ağ haritalamaları ${ }^{2}$ incelenen konularla ilgili birçok çalışmayı bir arada görselleyerek, anlamlı çıkarım ve yorumlar yapabilme imkanı sunmaktadır (Gürdin, 2020).

Bu çalışmanın amacı "yerel yönetimler" ve "bütçe" anahtar kelimeleriyle kamu yönetimi ve maliye alanındaki atıf indekslerine giren araştırma makalelerindeki ortak yönleri bulmak ve literatürün nasıl şekillendiğini ortaya koymaktır. Ayrıca çalışma, en çok atıf alan ilk 30 makaleyi inceleyerek bu alanda eğilimin ve popüler konuların neler olduğunu tespit etmektedir. Bu amaçla çalışmanın ilerleyen aşamaları üç bölümden oluşmaktadır. İlk bölümde kullanılan yöntem olan Bibliyometrik analiz, ağ analizi ve metin madenciliği hakkında bilgi verilmekte ve hazırlık aşamasında veri setlerine dair kararlar aşamalı olarak ve gerekçeleriyle sunulmaktadır. İkinci bölümde VOSviewer programıyla elde edilen çalışmaların yıllar bazında dağılımı, kurum ve ülke iş birlikleri, ortak yazarlık ve anahtar kelime

\footnotetext{
${ }^{1}$ İlk on dokuzuncu yüzyılda bibliyografya incelemeleri olarak kullanılmaya başlanan bu çalışmalar, yirminci yüzyılın üçüncü çeyreğinden itibaren kitaplar vb. materyallerin matematiksel ve istatistiksel yöntemlerle uygulanması şeklinde tanımlanmıştır. Günümüzde Bibliyometrik analizleri en kısa biçimde "literatürün gelişimi ve dağılımı ile ilgili istatistiksel çalışmalar" olarak özetlemek mümkündür (Çelikkaya \& Atila, 2020: 71).

2 Bilimsel ağ haritalama çalışmaları literatürün genel yapısını, yayınlara ait konular, anahtar sözcükler, yayınlandıkları ülkeler, yayın tarihleri ve yazarlar gibi değişkenler vasıtası ile analiz edilebilmesine olanak sağlayan çalışmalardır (Tabak vd., 2016: 119).
} 
ilişkileri değerlendirilmektedir. Son bölümde ise yerel yönetimler ve bütçe ile ilgili en çok atıf alan otuz makalenin içeriği incelenmektedir.

\section{YÖNTEM}

Belli bir bilimsel alandaki ana konular veya araştırma alanlarını belirlemek ve bunların birbirleriyle ilişkilerini tanımlamak için kullanılan bibliyometrik araştırmalar genellikle anahtar kelimeler, yazarlar veya ülke işbirliği ağlarının analizini temel almaktadır (Waltman vd., 2010). Bibliyometrik araştırmalar uzun bir geçmişe sahiptir. Erken dönem çalışmaları 1960'lara ve 1970'lere kadar uzanmaktadır (De \& Price, 1976; Kessler, 1963) 1960'lardan günümüze bu çalışmalarda bir çok farklı metodoloji kullanıldığı görülmektedir (Boyack vd., 2005; Klavans \& Boyack, 2006; Leydesdorff \& Rafols, 2009; Small \& Sweeney, 1985; Small vd., 1985; White \& Griffith, 1981).

$\mathrm{Bu}$ araştırmada bibliyometrik analizleri kolaylaştırıp bilimsel haritalamayı sağlayan VOSviewer yazılım programından faydalanılmıştır. VOSviewer programı büyük veriden anlamlı bilgi üretmeye yarayan grafik temsil ve görselleştirme ağırlıklı bir metin madenciliği uygulamasıdır. VOSviewer programının, SPSS ve Pajek gibi diğer programlara nazaran en büyük avantajı ise büyük veri setlerini daha sade ve kolay yorumlanabilir bir şekilde haritalamasıdır (van Eck \& Waltman, 2010: 2016). Bibliyometri analizi bir metin madenciliği türüdür. Bu analiz belli kelime öbeklerinden karmaşık ilişkilerin görselleştirilmesini sağlamakta, anlaşılır yorumlanabilir ve anlamlı sonuçlara ulaşılmaktadır (Artsın, 2020). Metin madenciliği bir akademik disiplinde ya da herhangi bir konuda değişen fenomenin belirlenmesini sağladığı gibi ve literatürde de ortaya çıkan değişimin sunulmasına da yardımcı olmaktadır (Delen \& Crossland, 2008; Scherf vd., 2005). VOSviewer programı sayesinde belli bir akademik alanda ya da disiplinler arası çalışmalar, konular, atıf, yazar, ortak yazar, yıllara göre dağılım gibi analizlere ulaşılabilmektedir (Artsın, 2020). Bibliyometrik araştırımalar belli bir zamandan günümüze kadar yapılan araştırmalardan çıkarım yaparak, geleceğe yönelik tahminde bulunma amacını da taşımaktadır (Morris vd., 2002). Disiplinler arası çalışmalarda yıllar bazında eğilimin gelişimi ve dergilerin ilgi gösterdiği konuların tespitiyse akademisyenlerin güncel eğilimleri tespit edip, çalışmalarını bu alanlarda yoğunlaştırmalarına yardımcı olabilmektedir.

Çalışmada kullanılan veri seti Web of Science'ın çekirdek koleksiyonundan (WoS Core Collection- SCI-Expanded, SSCI, A\&HCI, CPCI-S, CPCI-SSH, BKCI-S, BKCI-SSH, ESCI) derlenmiştir. Derlemede arama kelimeleri olarak "local governments" veya "local government" ve "budget" terimleri çalışmaların başlık, özet ve anahtar kelimeleri içerisinde aranmıştır. İkinci aşamada alan dışı sonuçların engellenmesi için alan olarak "Economics" veya "Public Admiınistration" veya "Political Science" veya "Urban Studies" veya "Law" veya "Social Sciences Interdisciplinary" kısıtlamasına gidilmiştir. Genel resmi görme adına bu alanın tarihsel seyri, kurum, ülke ve yazar iş birliklerine bakılmıştır. Aynı zamanda ilgili makalelerde anahtar kelimelerin ağ haritası çıkarılmıştır. Son aşamada ise en çok atıf alan ilk 30 makalenin içeriği kapsamlı incelenerek popüler konuların neler olduğu tespit edilmiştir.

\section{ANALIZZ VE BULGULAR}

Çalışmada ilk aşamada yerel yönetimeler ve bütçeye yönelik çalışmaların genel haritası ve eğilimler tespit edilmeye çalışılmıştır. Bu kapsamda 1980'den günümüze kadar indekslenen ilgili literatürdeki yayınların kurum, ülke ve yazar iş birlikleriyle ve anahtar kelime ilişkileri ele alınmıştır.

Şekil 1: Yayınların Yıllar İtibariyle Dağılımı

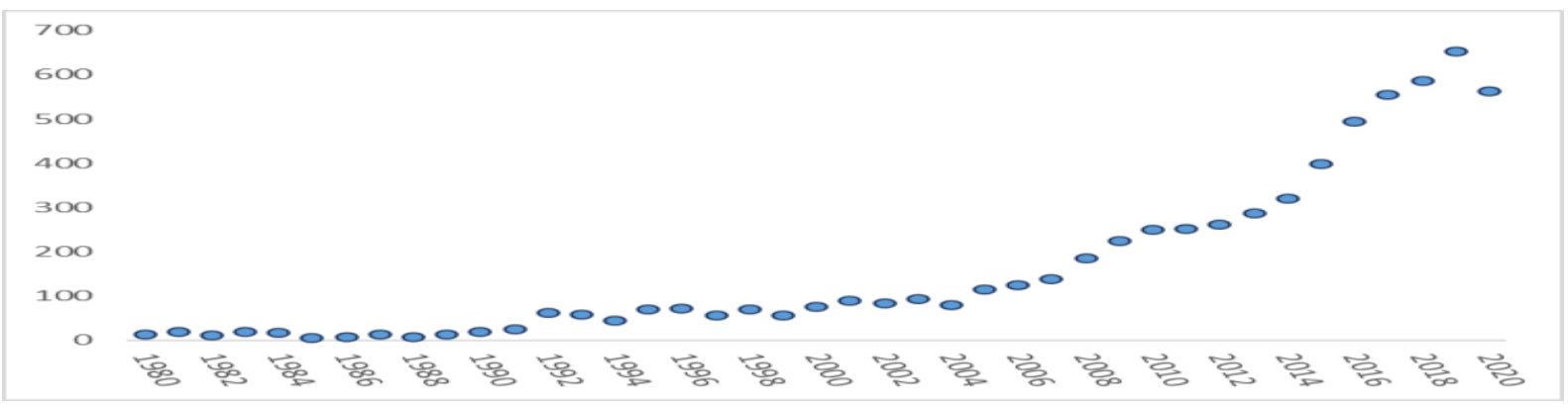

Kaynak: Veriler, WOS çekirdek koleksiyonundan derlenerek tarafımızca oluşturulmuştur. 
Şekil 1'de yayınların yıllar itibari ile dağglımı sunulmuştur. Birkaç istisna yıl hariç olmak üzere yayın sayısının her geçen gün arttığı; özellikle 2004 sonrasında artışın hızlandığı görülmektedir. Artan araştırma sayısının mali konular ve yerinden yönetim anlayışının gündemde yer almasına bağlı olduğu düşünülmektedir. Ayrıca yerel yönetimlerin güçlenmesinin, akademik alanda da yerel yönetimler konusu ve araştırmalarına olan ilgiyi arttırmış olması muhtemeldir.

\subsection{Kurum İş Birliği}

Bibliyometrik analizde ilk incelenen öğe kurumların iş birliği olmuştur. Şekil 2'de kurumlara ait ağ analizi, Şekil 3'te en etkili beş kurum, Şekil 4'te ise en çok atıf alan beş kuruma ait bilgiler sunulmuştur.

Şekil 2: Kurum İş Birliği Ağ Haritası

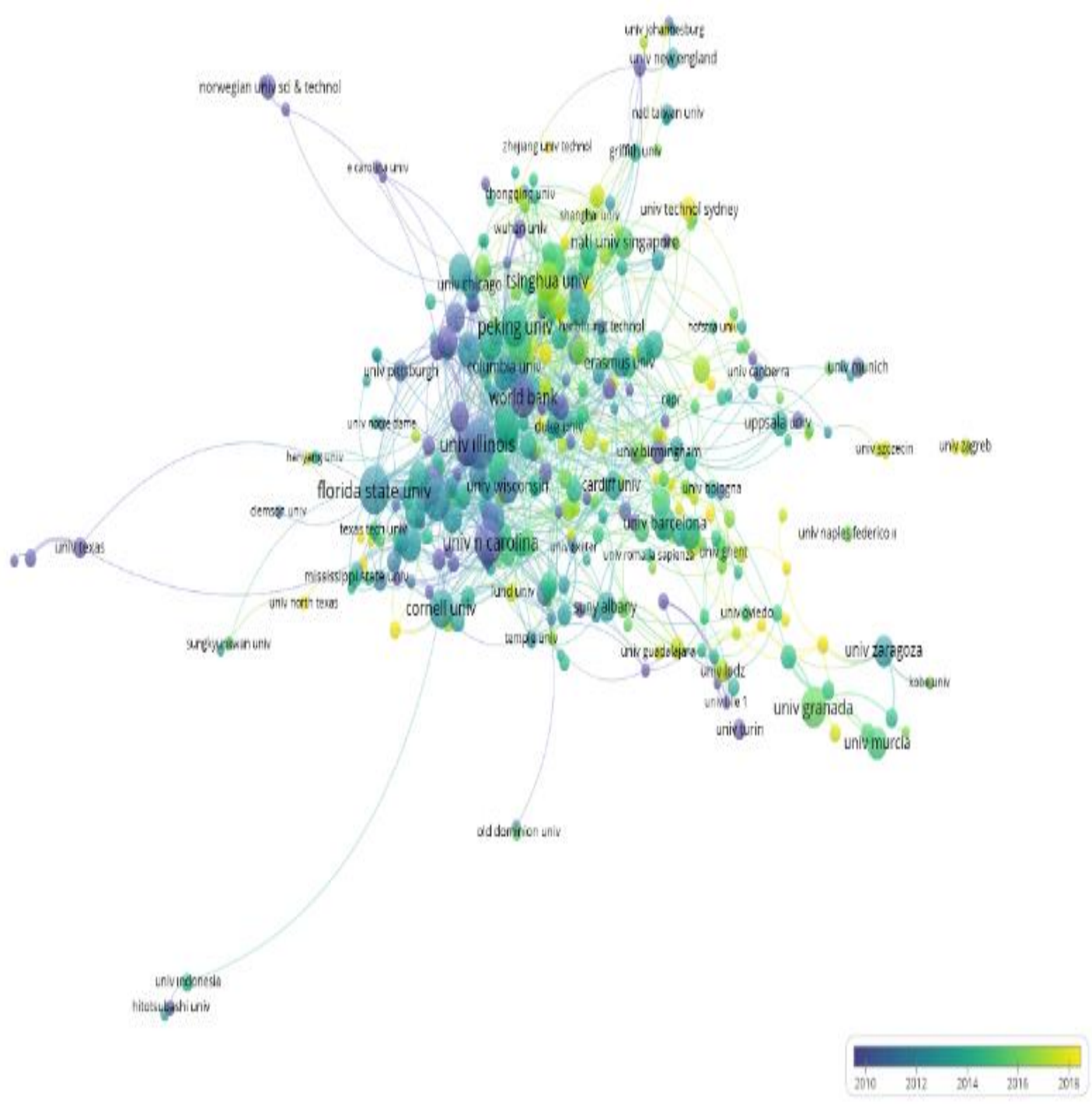

Kaynak: Veriler WOS çekirdek koleksiyonundan derlenerek tarafımızca oluşturulmuştur.

Şekil 2 incelendiğinde bağlantı gücü en yüksek kurum olarak Pekin Üniversitesi karşımıza çıkmaktadır. Pekin üniversitesi adresli ilgili literatürde 51 doküman 831 atıf mevcuttur. En çok atıf alan çalışmalarla beraber değerlendirildiğinde bu durum, özellikle, sosyalist rejimden kapitalist rejime geçişte ve küresel ekonomiye entegrasyonunda bölgesel sanayileşmeyi öncüleyen Çin'in yerel ve bölgesel yönetimlere ciddi yetki, mali kaynak ve teşvik sağlamasına yönelik reformların yansıması olarak yorumlanabilir. Aynı zamanda hızlı bir geçiş yaşaması, çok kısa sürede ekonomik büyümede 
ilk sırada yer alması ve özü itibariyle Batı'ya alternatif bir ekonomik büyüme modeli sunması bakımından araştırmaların çeşitlendiği ülke konumuna yerleşmiştir. Esas itibariyle geçiş ekonomisi olması sebebiyle Çin araştırmacılara, yerel yönetimler, devlet sistemi, ekonomik düzen ve mali reformların uygulanmasıyla piyasa mekanizmasının sağlanıp sağlanamadığının test edildiği bir laboratuvar ortamı sunmuştur. Aynı zamanda Batı menşeili ekonomi, kamu yönetimi ve maliye akademisyenlerinin Batı modelini baz alarak ürettikleri teori ve uygulamaları yıkması bakımından akademik araştırmalarda ilgi çekici hale gelmiştir.

İlk beşteki Pekin Üniversitesi hariç tüm kurumların Amerika Birleşik Devletleri (ABD) adresli olduğu görülmüştür. Bağlantı gücü yüksek ilk üç kurum üniversiteler iken, dördüncü kurumun Dünya Bankası, beşinci kurumun ise ABD merkezli Ulusal Ekonomik Araştırma Bürosu (National Bureau of Economic Research-NBER) olduğu belirlenmiştir. Sonuç olarak, yerel yönetimler ve bütçe ile ilgili araştırmaların sadece üniversitelere bırakılmadığı ve uluslararası örgütler ile araştırma merkezlerinin de bu alanda çalıştığ 1 tespit edilmiştir.

Şekil 3: Kurum İşbirliğinde En Etkili 5 Kurum

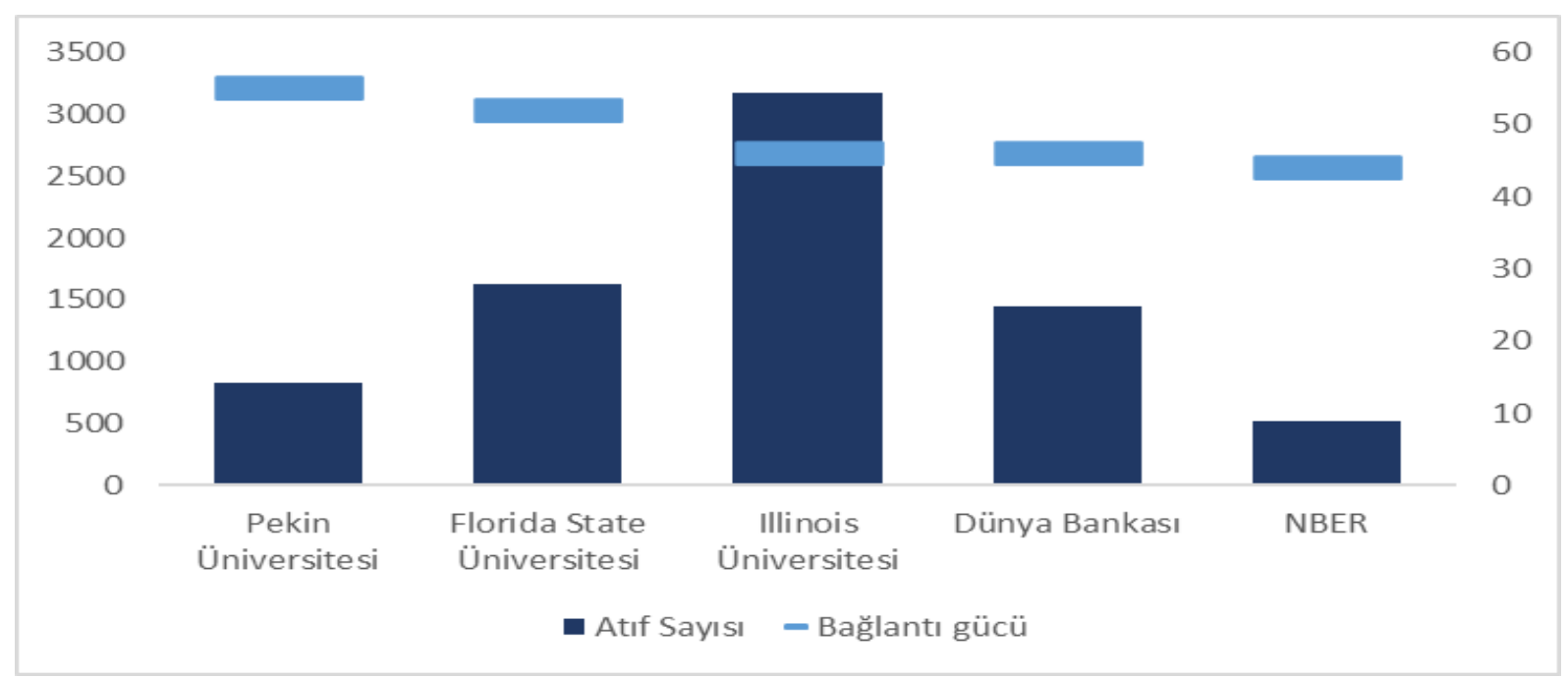

Kaynak: Veriler WOS çekirdek koleksiyonundan derlenerek tarafımızca oluşturulmuştur.

En çok atıf alan kurumlara yer verilen Şekil 4 incelendiğinde merkezi konumda yer alan kurumlardan Illinois Üniversitesi 3174 atıf ile ilgili literatürde en çok atıfı alan çalışmalara sahip olan kurum olarak görülmektedir. En etkili kurumlarda olduğu gibi en çok atıf alan kurumların da ABD ağırlıklı olduğu, ilk beş kurumun tamamının ABD üniversitelerinden oluştuğu tespit edilmiştir.

Şekil 4: Kurum İşbirliğinde En Çok Atıf Alan 5 Kurum

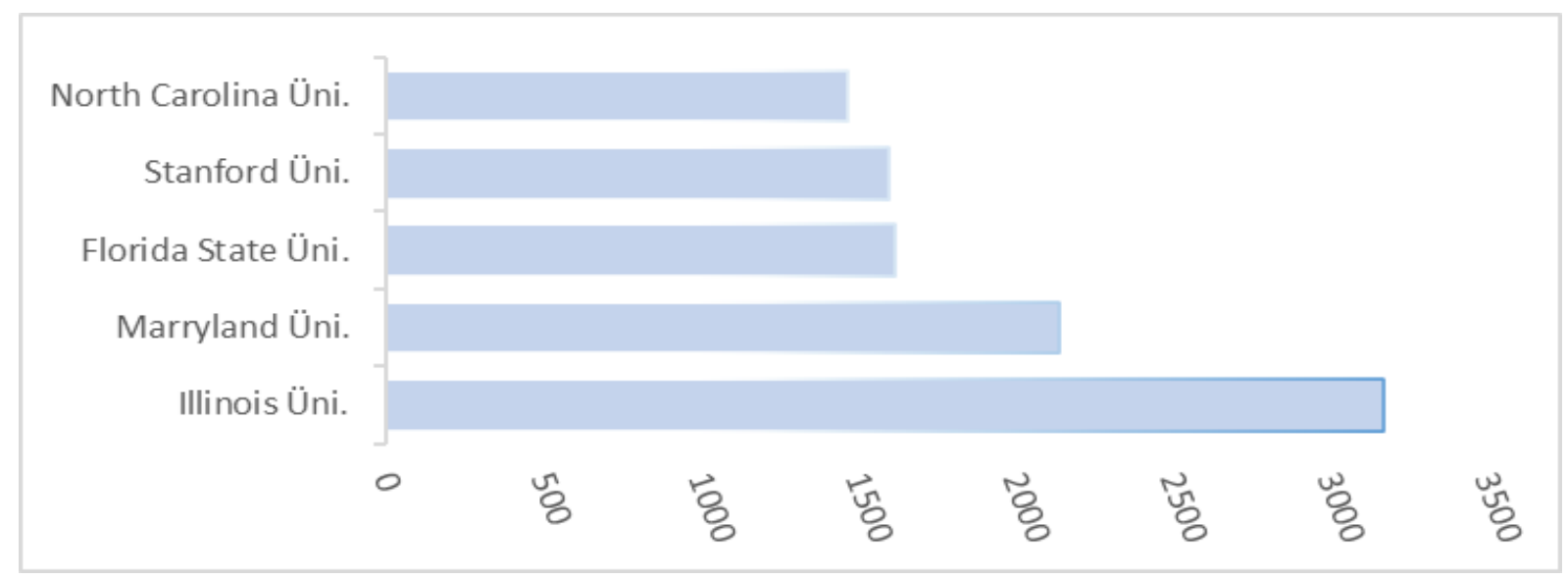

Kaynak: Veriler WOS çekirdek koleksiyonundan derlenerek tarafımızca oluşturulmuştur. 


\section{2. Ülke İş Birliği}

Şekil 5 ülke iş birliklerine ilişkin ağ analizini, Şekil 6 en etkili beş ülkeyi, Şekil 7 ise en çok atıf alan ülkeleri göstermektedir.

Şekil 5: Ülke İş Birliği A ̆g Haritası

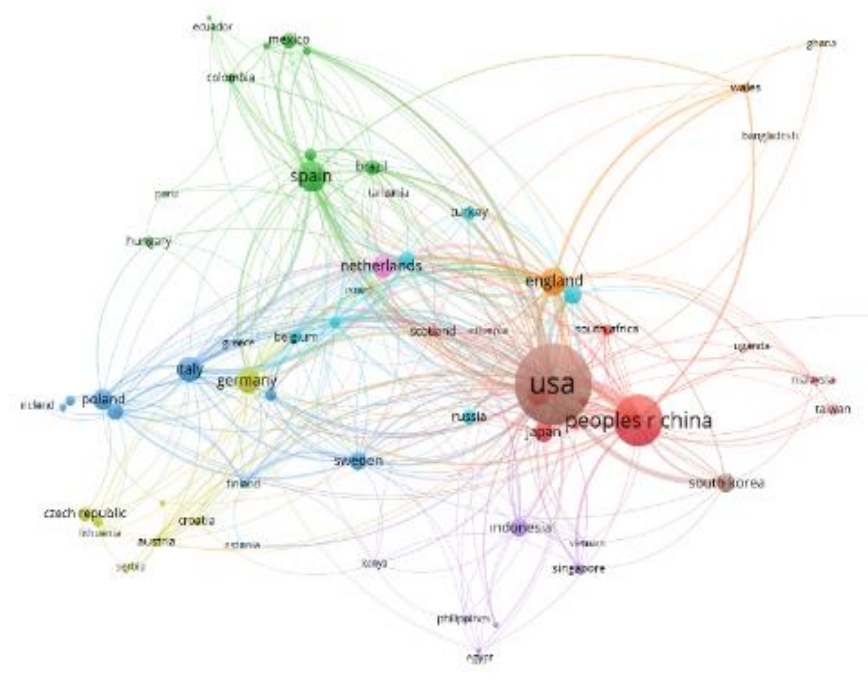

Kaynak: Veriler WOS çekirdek koleksiyonundan derlenerek tarafımızca oluşturulmuştur.

Kurum iş birliğine ilişkin ağ analizine paralel sonuçların elde edildiği ülke iş birliği ağ haritası Şekil 5'te incelendiğinde, ABD ve Çin'in en etkili iki ülke olarak ağın merkezinde yer aldığı; İngiltere, İtalya ve Almanya'nın ise onları izlediği görülmektedir. ABD'nin bağlantı gücü 2242 doküman üzerinden 515 iken, beşinci sıradaki Almanya'nın bağlantı gücü ancak 198 dokümanda 111 olarak hesaplanmıştır. Türkiye ağ haritasında İngiltere'nin sol üstünde yer alırken 63 dokümanda, 14 bağlantı gücüne sahip olduğu tespit edilmiştir. Bu duruma sebep olan temel dinamiğin Türkiye adresli yayınların azlığı, bu yayınlara yapılan atıfların az olması ve etki faktörü düşük dergilerden yapılması olarak tahmin edilmektedir.

Şekil 6: Ülke İş Birliğinde En Etkili Ülkeler

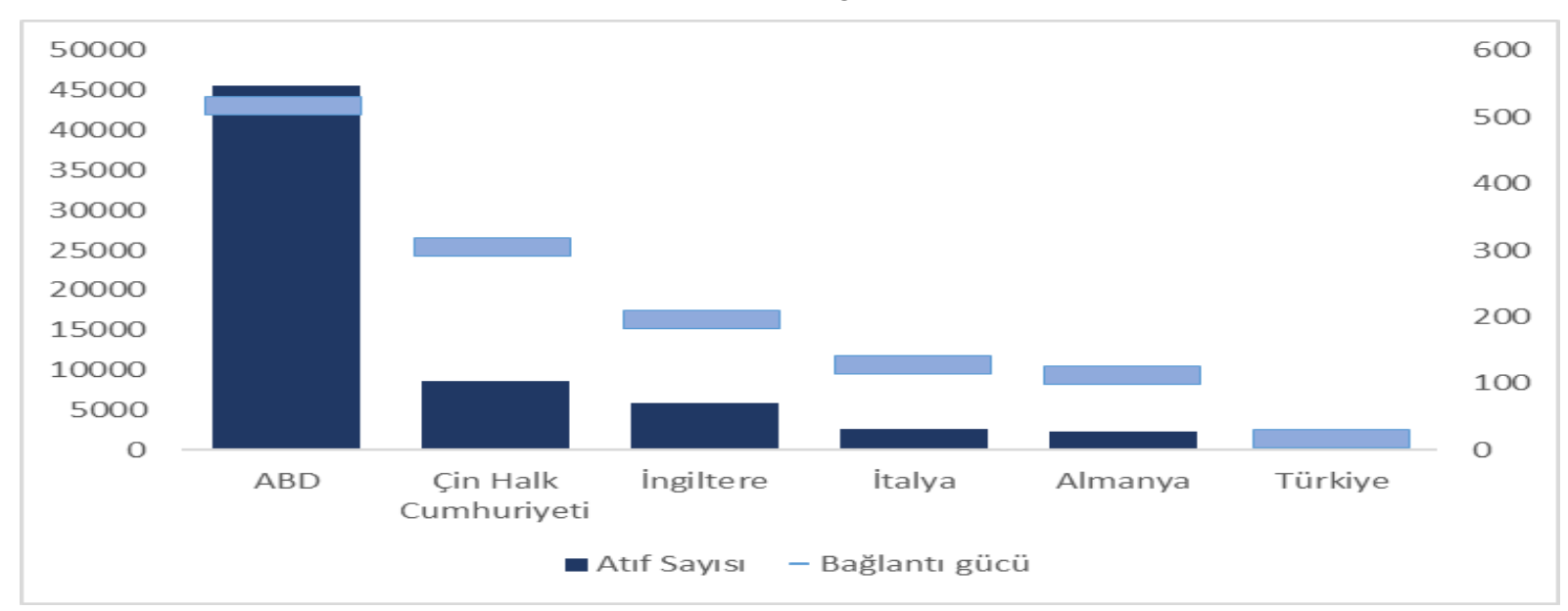

Kaynak: Veriler WOS çekirdek koleksiyonundan derlenerek tarafımızca oluşturulmuştur. 
En çok atıf alan yayınlar 45,585 atıf ile ABD adresli olarak tespit edilmiştir. İkinci sırada olan Çin Halk Cumhuriyeti'nin ise 8658 atfı mevcuttur. Tüm atıflar incelendiğinde ABD adresli yayınların yaklaşık olarak literatürdeki diğer toplam yayınların aldığı atfa eşit olduğu tespit edilmiş̧ir. Türkiye adresli yayınların özelinde ise toplam olarak 202 atıfın yapıldı ğı görülmektedir.

Şekil 7: Ülke İş Birliğinde En Çok Atıf Alan Ülkeler

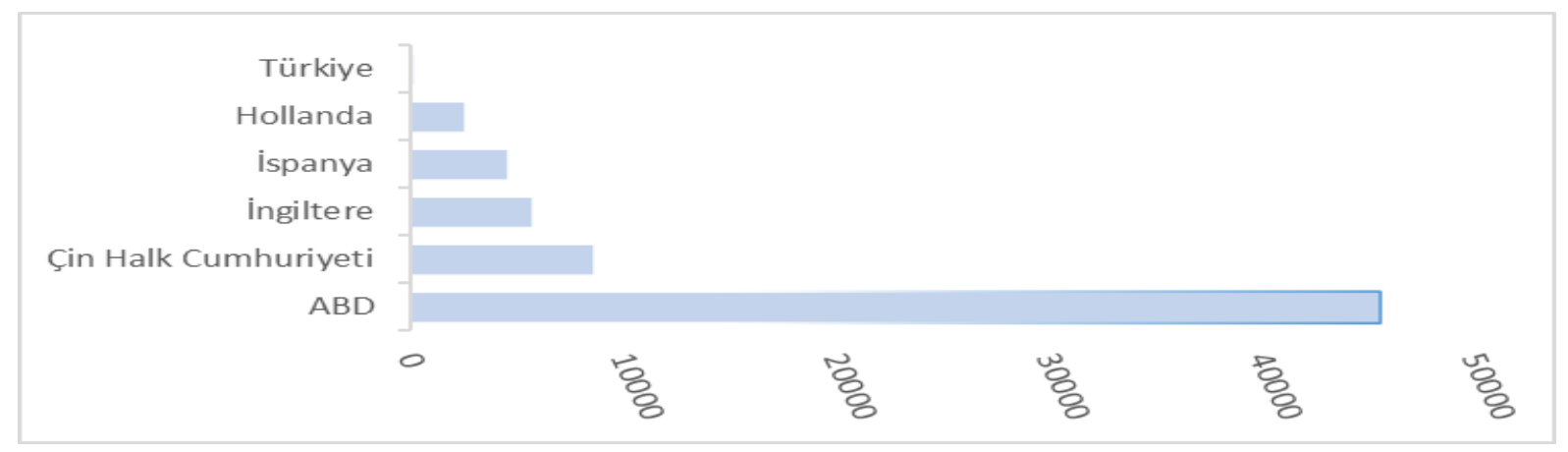

Kaynak: Veriler WOS çekirdek koleksiyonundan derlenerek tarafımızca oluşturulmuştur.

\subsection{Ortak Yazarlık}

$\mathrm{Bu}$ bölümde yerel yönetimler ve bütçe ile ilgili yapılan çalışmaların yazar/akademisyen özellikleri incelenmiştir. Şekil 8 ve 9'da ortak yazarlık ağ haritası verilmekte, Şekil 10'da en etkili ilk beş yazar, Şekil 11' de ise en çok atıf alan yazarlar gösterilmektedir.

Şekil 8: Ortak Yazarlık Ağ Haritası-1

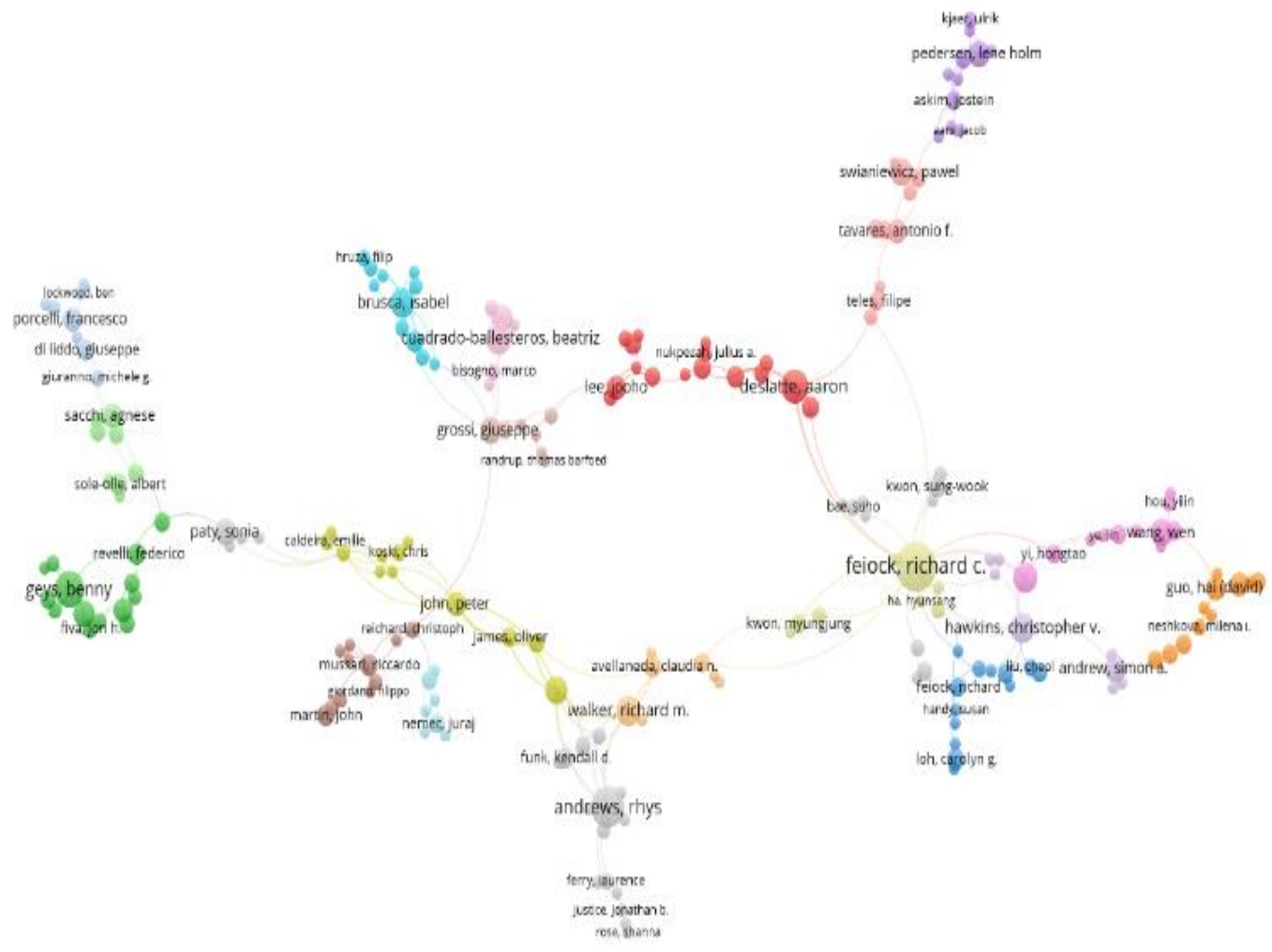

Kaynak: Veriler WOS çekirdek koleksiyonundan derlenerek tarafımızca oluşturulmuştur.

Ortak yazarlık haritasında birkaç kilit yazarın bağlantısı ile akademik ağın bütünleşmesinin sağladığı gözlemlenmektedir. Analizde her birin yazarın maksimum 25, minimum 2 makalesi dikkate 
alınmıştır. Ağda yer alan 10252 yazar arasında 1433 eşik tespit edilmiş ancak birbiri ile bağlantılı en yüksek ağ olan 208 yazar ile ağ oluşturularak Şekil 8'de bağlantısız ağ haritas1 ile de Şekil 9'da sunulmuştur. Benito, Bernardino 22 makale, 354 atıf ve 43 bağlantı gücü ile ağın merkezinde yer almaktadır. Feiock, Richard 24 makale, 636 atıf 36 bağlantı gücü ile ikinci en güçlü bağlantıya sahip yazar olarak karşımıza çıkmaktadır.

Şekil 9: Ortak Yazarlık A $\breve{g}$ Haritası-2

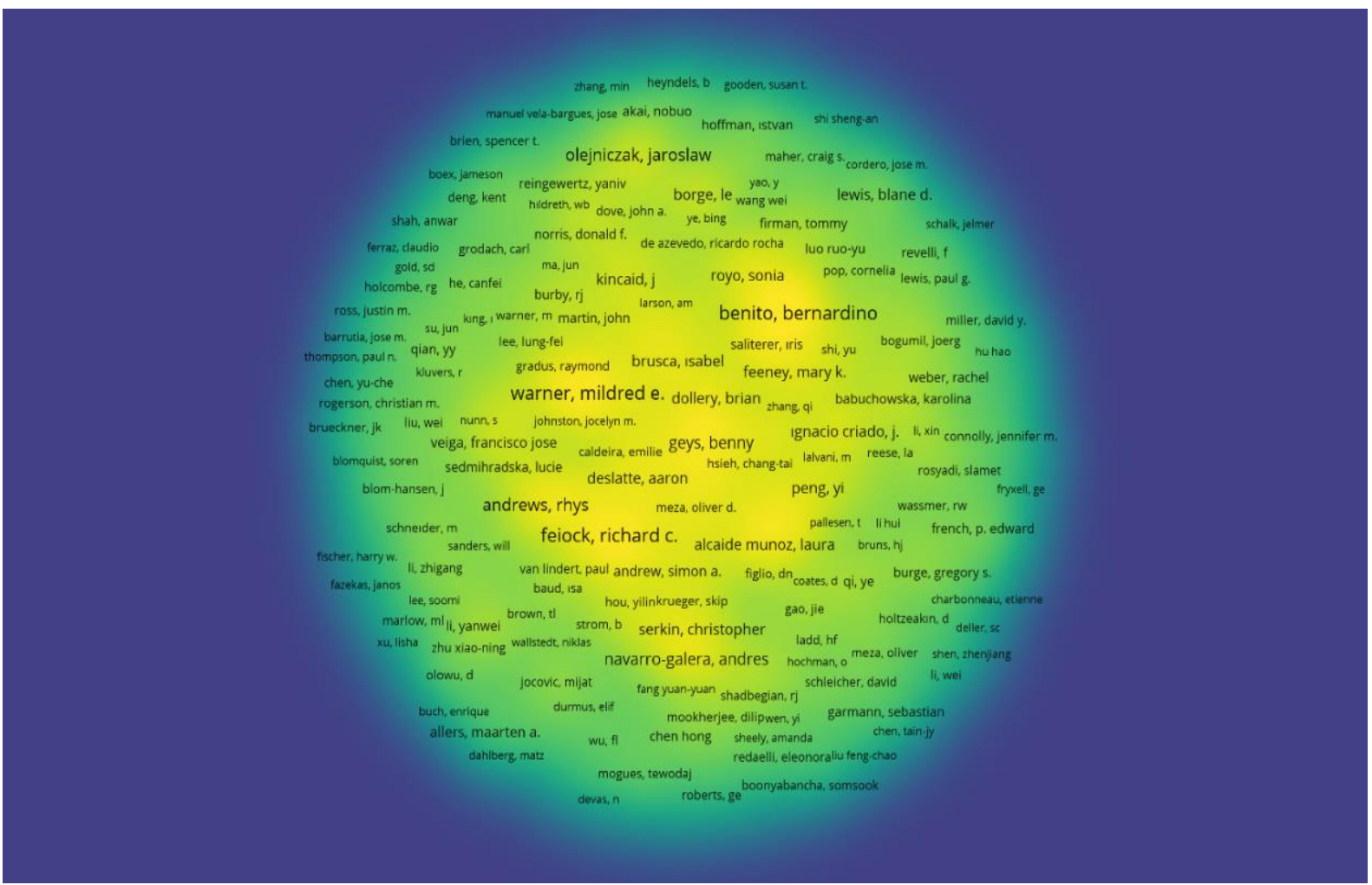

Kaynak: Veriler WOS çekirdek koleksiyonundan derlenerek tarafımızca oluşturulmuştur.

Şekil 10: Yazar İş Birliğinde En Etkili Beş Yazar

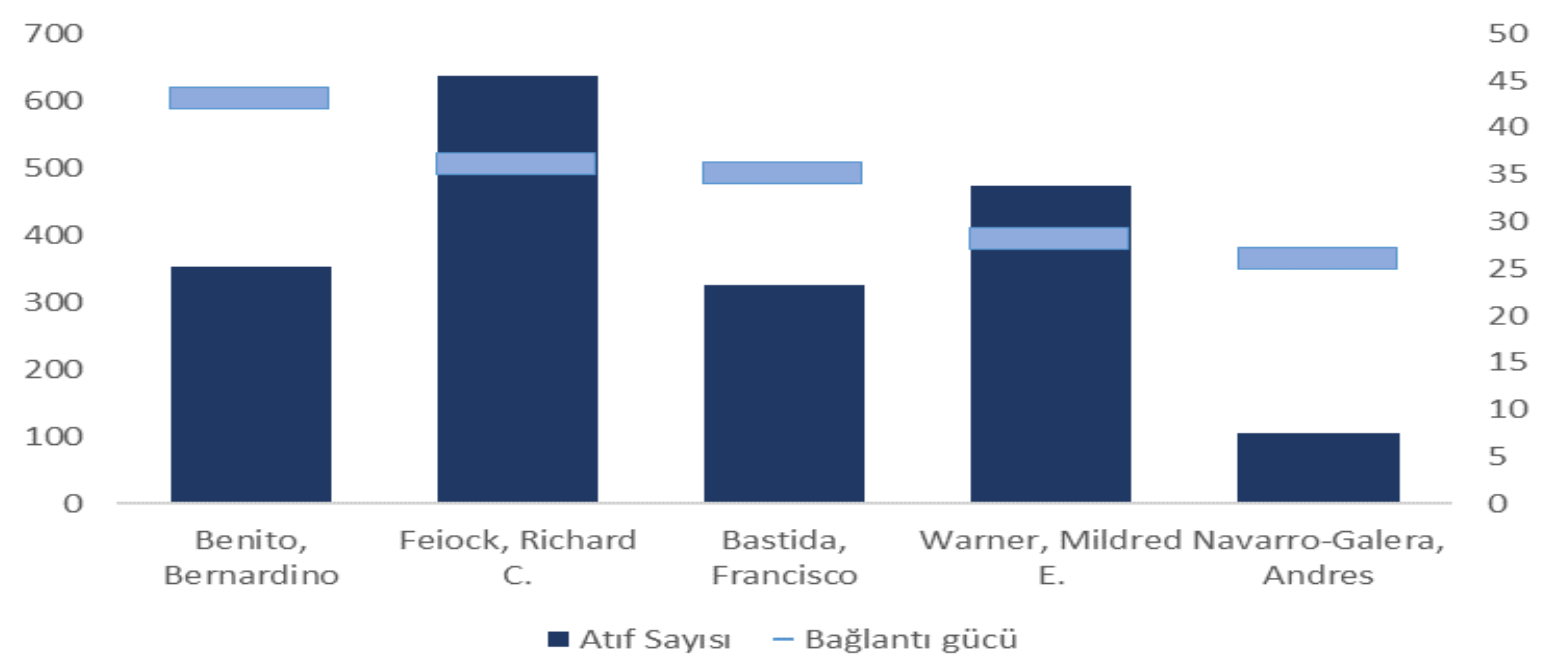

Kaynak: Veriler WOS çekirdek koleksiyonundan derlenerek tarafımızca oluşturulmuştur.

En çok atıf alan beş yazarın aldığı atıf sayısının görüldüğü Şekil 11'de etkili yazarlar sıralaması ile büyük farklılıklar gösterdiği belirlenmiștir. Bu farklılığın en temel nedeni en çok atıf alan makalelerin tek yazarlı olmasıdır. En fazla atıf alan yazar olan Oates, Wallace E.'nin iki makalesinin 1400'ün üzerinde atıf aldığı, Qian, Yinyi'nin ise yine iki makalesine yapılan atıfların 
sayısının 1079 olduğu tespit edilmiştir. En etkili ve en çok atıf alan beş yazarda ortak olan tek isim 24 doküman ve 636 atıf ile Feiock, Richard C. olmuştur. Dolayısıyla Feiock, Richard C.'nin hem akademik camiadaki benzer konuları çalışanlarla bağlantı sayısının hem ortak yazarlı çalışmalarının ve hem de atıf oranının yüksek olduğu gözlemlenmiştir.

Şekil 11: En Çok Atıf Alan Beş Yazar

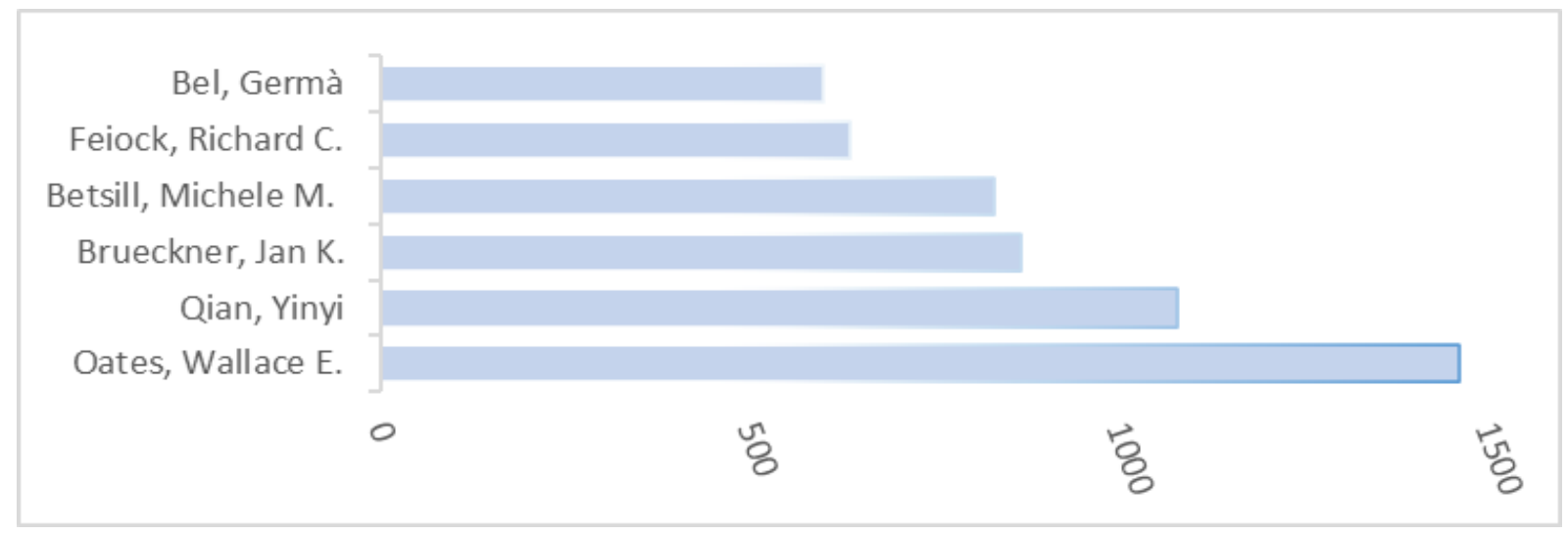

Kaynak: Veriler WOS çekirdek koleksiyonundan derlenerek tarafımızca oluşturulmuştur.

\subsection{Anahtar Kelime}

Yerel yönetimler ve bütçe ilişkisinin ağ analizi taramasında makalelerde yer verilen ilk üç kelime (local government, local governements, budget) üzerinden yapılan anahtar kelimelerin ağ haritası Şekil 11'de sunulmuştur.

Şekil 12: Yerel Yönetim ve Bütçe Makalelerindeki Anahtar Kelimeler
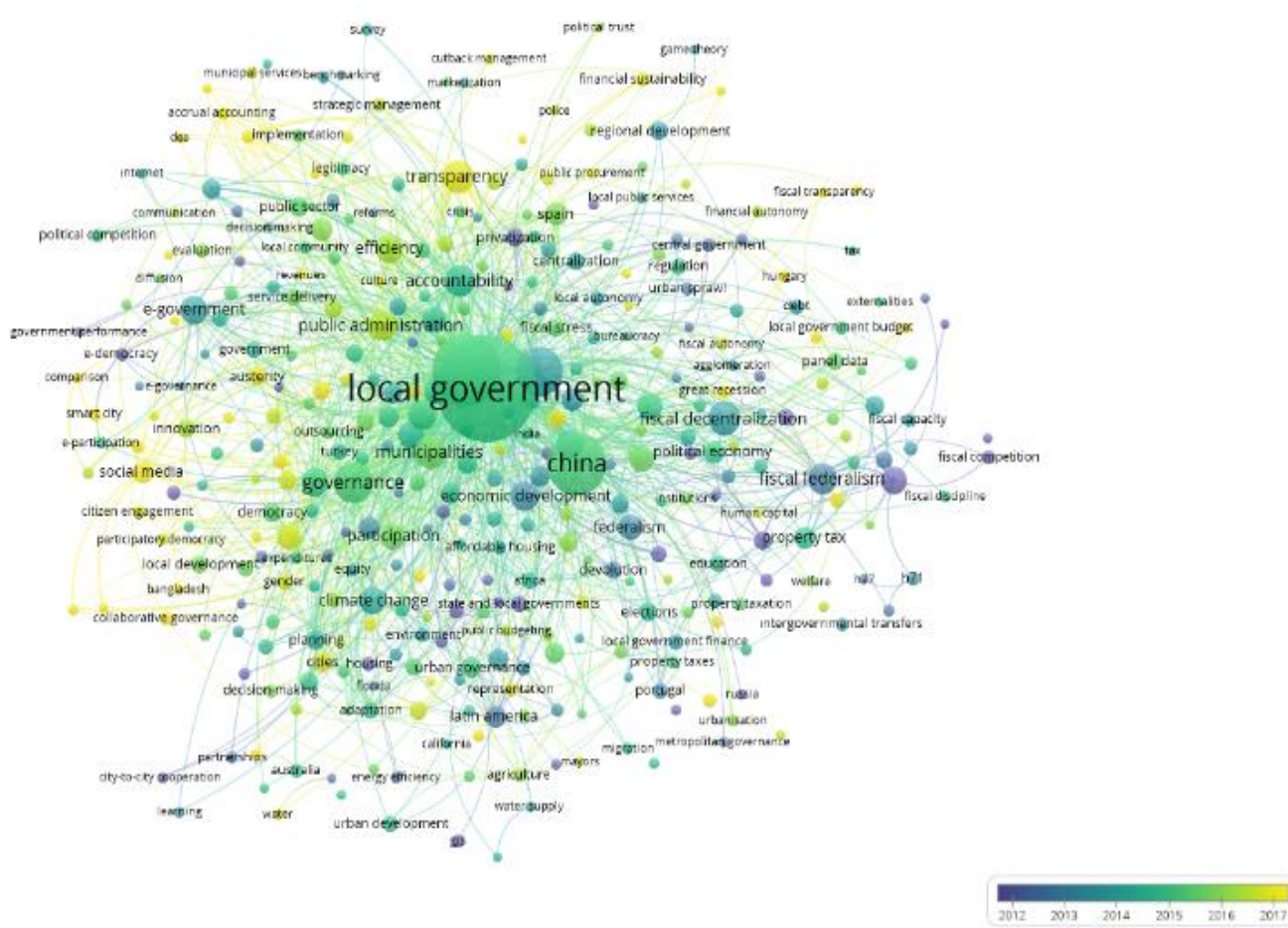

Kaynak: Veriler WOS çekirdek koleksiyonundan derlenerek tarafımızca oluşturulmuştur.

Şekil 12'de açıkça görülüğü üzere kelime bazlı taramada en merkezi konumda yer alan kelime yerel yönetim(ler) (local governments) olmuştur. Yerel yönetimler $1025 \mathrm{kez}$ kullanılmış ve 1482 bağlantı gücüne ulaşmıştır. Yerel yönetimler bütçe ilişkisinde en çok kullanılan ikinci anahtar kelime Çin (China) olmuştur. Çin anahtar kelimesi 238 çalışmada kullanılmış ve 259 bağlantı gücü 
hesaplanmıştır. En çok kullanılan diğer anahtar kelimeler ise desantralizasyon (decentralization - 150 çalışma-272 bağlantı gücü), kamu yönetimi (public administration-109 çalışma, 214 bağlantı gücü) ve mali desantralizasyon (fiscal decentralization - 72 çalışma, 80 bağlantı gücü) olmuştur.

\section{EN ÇOK ATIF ALAN 30 MAKALENIN DETAYLI İNCELEMESİ}

Çalışmanın ilk aşamasında yerel yönetimler ve bütçe ile ilgili yapılan çalışmaların genel çerçevesi ve özellikleri değerlendirildikten sonra, bu aşamada en çok atıf alan ilk 30 makale incelenmiştir. Burada amaç, hem genel eğilimin ve popüler konuların ne olduğunu tespit etmek, hem de gelecek eğilimler hakkında yorumda bulunarak bu alanda çalışmak isteyen akademisyenlere yol göstermektir.

Oates (1999) çalışmasında, 20. yüzyılın başlarından sonlarına değin mali federalizmin gelişimini, sanayileşmeye beraber kentlerde yetki devrinin yaşanmasını ve merkezileşmeden desantralizasyon yönelimler dolayısıyla kentsel yönetimlerin bütçelerinin artmasını ve dikey hiyerarşinin uğradığı dönüşümü aktarmıştır. Geleneksel mali federalizmdeki yönetsel işlemlerin bölüşümü, mali desantralizasyonun refaha katkısı ve kullandıkları mali araçları tartışmış; yüzyılın sonlarında yaşanan değişim, deneysel federalizm, yargı organları arası rekabet ve çevresel federalizm, mali federalizmin siyasal ekonomisi, piyasayı koruyucu federalizm ve gelişmekte ve geçiş ülkelerindeki mali desentralizasyon konuları değerlendirilmiştir.

Montinola vd. (1995), Çin'de ekonomik reformlar sonrasında yaşanan ekonomik büyümenin bilinen doğruları sarstığını düşünerek, bunların nedenlerini araştırmışlardır. Çalışmada sosyalist rejimden yeni çıkan ekonominin mülkiyet haklarının dahi gelişmediği bir ortamda bu kadar hızlı büyümesinin nedenleri sorgulanmıştır. Çinin ekonomik büyümesinin ardındaki siyasal dayanağın federalizm olduğu; piyasa korumasına dayalı federalizm ile yerel yönetimlerin ekonomik kalkınmaya yönelik faaliyetlerini teşvik eden desantralizasyonu öncüleyen reformların "Çin tarzı federalizm" in ortaya çımasına katkıda bulunduğunu öne sürmüşlerdir. Aynı zamanda Çin modeli federalizmde yerel yönetimlerin ekonomide Batı modelinden daha fazla merkezi rol aldıkları ve mali desentralizasyon ile yerel yönetimlere yönelik ekonomik reform teşviklerinin bunda etkili olduğu iddia edilmiştir.

Oi (1992), Çin'de gerçekleştirilen mali reformların yerel kamu görevlilerinin mali ve özellikli endüstriyel gelişmeyle ilgili teşviklerini nasıl arttırdığını incelemiştir. Bu amaçla kırsal alandaki köy, kasaba ve eyaletler seçilerek farklı birimlerden sorumlu 222 kamu görevlisiyle görüşmeler gerçekleştirmiştir. Çalışma ilk olarak reformların yerel vergilerin toplanmasında getirdiği değişiklikleri ele almış, ikinci olarak yeni teşvik ve uygulamalara değinilmiş, üçüncü olarak yerel yönetimlerin neden kırsal sanayileşmeyi tercih ettikleri açılanmıştır. Son bölümde yerel yönetimlerin yerel çıkarları maksimize etmek için ekonomik faaliyetleri nasıl eşgüdümleyip planladıklarını incelemiştir. Çalışmada bireylerin mülkiyet hakları olmasa dahi ekonomik büyümenin sağlanabileceğini elde edilen temel sonuç olarak karşımıza çıkmış ve yerel devlet kooperatifçiliğini benimseyen Çin büyüme modelinin özelleştirmenin alternatifi olarak başarılı olabileceğini ve kırsal sanayileşmenin ekonomik büyümede küçümsenmemesi gerektiği savunulmuştur.

Behn (2003) çalışmasında, kamu yöneticilerinin neden performans ölçümüne gerek duyduklarını açıklamaktadır. Yöneticiler sekiz farklı amaç için performans değerlendirmesine ihtiyaç duymaktadır. Bunlar örgüt değerlendirmesi, denetim, bütçe, motivasyon, terfi, ödüllendirme, öğrenme ve gelişmedir. Ayrıca performans ölçümü ve değerlendirmesinde her koşula uyan tek tip standart bir performans ölçümünün bulunmadığını, dolayısıyla yöneticilerin, gelişmeyi sağlamak amacıyla neyi ve nasıl ölçeceklerini bilmeleri gerektiğini savunmaktadır.

Bulkeley ve Betsill (2005), sürdürülebilir kentlerin bir hedef olarak teşvik edilmelerine rağmen bu sürdürülebilirliğin nasıl sağlanacağına yönelik bir cevabın bulunmadığını belirtilmektedir. Çok düzeyli yönetişimin sürdürülebilirlik hedefine hizmet edebileceğini iddia eden yazarlar, Newcastle upon Tyne gelişim planlamasında ve Cambridgeshire ulaşım planlamasında iklim korumasına yönelik uygulamaları incelemişlerdir. Sonuç olarak kentsel sürdürülebilirliğin "kentsel alan"ın sınırlarının ötesinde ve coğrafi ölçekleri de aşan yönetişim türleriyle şekillendiklerini gözlemlemişlerdir. İklim koruması gibi sürdürülebilir kente hizmet eden hedeflerin farklı düzeylerdeki otoritelerle işbirliğini gerektirdiğini savunmaktadırlar. 
Ho (2002), internetin yerel yönetimlere çeşitli imkanlar sunmasını ve yerel yönetimlerin edevlet uygulamalarıyla sanal platformlarda giderek artan oranda yer almalarını değerlendirmiştir. Yazar çalışmasında e-devlet hizmetlerinin maliyet-etkinliğinin yüksek olması, bürokrasiyi azaltması, standardizasyon ve departmanlaşma sağlaması gibi avantajlarından bahsetmektedir. Çok sayıda yerel yönetimin sanal ortamda sunduğu "tek hizmet merkezi" nin vatandaş odaklılığına, diş paydaşlarla iş birliğine ve gelişmeye yönelik "networking" gibi çeşitli faydalarını incelemiştir. E-devlet uygulamaları geleneksel devlet hizmetlerine alternatif bir paradigma gibi yorumlanmıştır. Ayrıca analizlerde 55 popüler Amerika kentinin web siteleri incelenerek bilgilendirme-odaklı, kullanıc1odaklı ve idari-odaklı olmak üzere sınıflandırılmıştır.

Brueckner (2003) çalışmasında, kamu ekonomisinin teorik çalışmalarında yönetimler arası stratejik etkileşime yönelik araştırmaların arttığı belirtilmiştir. Vergi-rekabeti yazınında yer alan çalışmaların kaynak-akış modeli ile yayılma modelleri altında sınıflandırılabildiği gözlemlenmiştir. Kaynak-akış modeline daha çok vergi rekabeti ve refah rekabeti ile ilgili araştırmalar yer alırken, yayılma modellerinde çevresel standartlarda, karşılaştırma (kıyaslama), kamu harcamalarında stratejik tercih çalışmaları bulunmaktadır.

Tolbert ve Mossberger (2006), hükümetlere azalan güven ve itimadın e-devlet uygulamalarıyla kazanılıp kazanılamayacağını değerlendirmiştir. Çalışma bir projenin verisini kullanarak, vatandaşların e-devlet kullanım sıklığı ve e-devlete karşı tutumlar ile hükümete güvenleri arasındaki ilişkiyi tespit etmeye çalışmıştır. Yerel yönetimlere güven ile yerel yönetimlerin elektronik uygulamaları kullanımı arasındaki ilişki yüksek düzeyde anlamlı çıkmıştır. Bu durum federe yönetim ve devlet yönetimine güvene de yansımaktadır. E-devlet uygulamalarının vatandaşlarla etkileşimi arttırma ve cevap verebilirlik algılarını değiştirme yoluyla süreç temelli güvenin arttırıldığı görülmüştür.

Jin vd. (2005), bölgesel desentralizasyon ve mali teşviklere dayalı Çin tarzı federalizmi araştırmışlardır. Çin'e ait bir panel veri setinin test edilmesi ile gerçekleştirilen analizlerde il idaresinin mali teşvikleriyle, ildeki piyasanın gelişmesi arasındaki ilişki incelenmiştir. Çalışmanın amaçlarından biri de yerelde piyasa mekanizmasının işleyerek ekonomik büyümeye katkıda bulunmasında desantralizasyondan ziyade güçlü mali teşviklerin çok daha önemli olduğudur. Çin'de çıkarılan mali reformların il idaresinin teşvikini güçlendirdiği ve ilin ekonomik gelişmesine katkıda bulunduğu belirtilmektedir. Sovyet Rusya ile yapılan karşılaştırmada ise, Çin'in bu teşviklerinin belirgin bir farkla piyasa etkinliği arttırıcı nitelikte olduğu ifade edilmektedir.

Oates (2005) çalışmasında, mali federalizm kuramındaki gelişmelerin yeni bir tür mali federalizme evrime yol açtığına, bu sebeple ikinci jenerasyon mali federalizmden bahsedilebileceğini savunmaktadır. Çalışmanın ilk kısımda geleneksel anlamda mali federalizm kuramı ele almıştır. İkinci kısımda ise federal sistemlerin işleyiş ve yapısında gerçekleşen yeni gelişmelerle, mali kurumların yeniden düzenlenmesi gereğine değinmektedir. Çalışma en çok atıf alan ilk makalenin yazarı tarafından kaleme alınmıştır.

Young (2000), sosyalizmden çıkan Çin'de piyasa ekonomisine yönelik reformları araştırmıştır. Çalışmasında merkezi kontrolün kademeli olarak kaldırıldığı sektörlerde, yerel yönetimlerin bu rantları kapmayı amaçladıkları belirtilmektedir. Bu rant kapma yarışının piyasaların bozulmasına neden olduğu ifade edilmektedir. Merkezi kontrolün kaldırılmasına dayanan kademeli reformlar piyasanın parçalı bir görünüm sergilemesine neden olmaktadır. Yerel yönetimlerin rant kapma adına bölgelerarası ticaret bariyerlerini arttırdığı ve nihai kertede iç piyasada parçalanma ve bölgesel sınai üretimin karşılaştırmalı avantajında bozulmalara sebep olduğu savunulmaktadır. Hatta bölgesel güçlerin piyasayı rant sağlama adına bozmalarını, Çin'in tek bir merkezi plandan, çoklu ve rekabet halindeki merkezi planlara geçtiği şeklinde yorumlamaktadır.

Qian ve Roland (1998) hükümetlerin, etkinlik sorunu olan ekonomik projelere yönelik kurtarma paketi teşviklerinin siyasal çıkar ile ekonomik maliyet arasında bir tercih zorunluluğuna neden olduğu ifade etmektedir. Çalışmaya göre bu durumun federalizme iki etkisi bulunmaktadır. İlki rekabet etkisi olarak adlandırılmaktadır ve yerel yönetimler arası mali rekabetin, kurtarma paketlerinin fırsat maliyetini arttırması durumudur. İkincisi ise kuvvetler ayrılığı etkisi olarak adlandırılmaktadır ve parasal merkezileşmeyle mali desentralizasyon arası çıkar çatışmaları, bütçe kısıtını zorlamakta ve 
enflasyonu düşürmektedir. Mali desantralizasyonun geçiş sürecinde, diğer alanlardaki geçişlere de etkiyen önemli bir reform aracı olduğu vurgulanmıştır. Bahsedilen etkiler Çin'in piyasa ekonomisine geçişi üzerinden ele alınmıştır.

De Lancer Julnes ve Holzer (2001) Amerika'da çok sayıda eyalet ve yerel yönetimin performans ölçüm sistemlerini geliştirmediklerini, geliştirenlerin ise bu sisteme karar verme mekanizmalarına bütünleşmiş etmediklerini iddia etmektedir. Araştırma bölgesel ve yerel yönetim çalışanlarına yapılan bir anket ile performans ölçümünün kullanımını etkileyen faktörleri incelemektedir. Çalışmanın amacı, performans ölçümünün kullanım kalıpları hakkında daha iyi bilgi edinmektir. Bu bilgiler, performans ölçüm kullanımını etkileyen faktörlere dayalı bir model geliştirmeye katkı sağlamıştır. Araştırmada politika uyarlamasının daha çok rasyonel ve teknokratik kuramlardan, uygulamanın ise örgüte özgü siyasal ve kültürel hususlardan etkilendiği sonucuna varılmıştır.

Burby (2006), Katrina kasırgasındaki kayıpların nedenlerini uygulamada federal hükümet, yerel yönetimler ve yasalardaki sıkıntılardan kaynaklandığını iddia etmektedir. Afet yönetiminde federal ve yerel düzeylerdeki iki paradoksun kayıpları arttırdığını savunmaktadır. Bunlardan ilki güvenli kalkınma paradoksudur. Federal hükümet, tehlikeli alanları daha güvenli hale getirmeye çalışırken, felaketle sonuçlanan mülk hasarları ve ekonomik kayıp potansiyelini önemli ölçüde artırmıştır. Diğeriyse yerel yönetim paradoksudur. Yerel çalışanlar, vatandaşlar acıların ve mali kayıpların yükünü çekerken savunmasızlığı sınırlandırmak adına yeterince politika üretememişlerdir. Çalışmada bu iki paradoksa rağmen, yerel yönetimlerin tehlike azaltmaya yönelik kapsamlı planlar hazırlaması halinde afet kayıplarının azaltılabileceği ifade edilmektedir.

Zhang ve Zou (1998) 1980-1992 dönemi için Çin'in 28 bölgesinde merkezi ve yerel yönetimler arasındaki mali kaynakların tahsisinin ekonomik büyümeyi nasıl etkilediğini araştırmıştır. Çalışma sonucunda mali ademi merkeziyetçiliğin yerel ekonomik büyümeye genellikle olumlu bir katk1 sağladığ1 şeklindeki geleneksel görüşün aksine mali desentralizasyon ile bölgesel ekonomik büyüme arasında negatif yönlü bir ilişkinin varlığını tespit etmiş̧lerdir.

Norris ve Moon (2005) Amerika Birleşik Devletleri’nde, ülke çapındaki iki anketten elde edilen e-devletin yerel yönetim tarafından benimsenmesi, web sitesi kompleksitesi, e-devletin algılanan etkileri ve e-devletin benimsenmesi ve karmaşıklığının önündeki engeller verilerini kullanarak yerel yönetimlerin e-devlet platformlarına ne kadar uyum sağladıklarını ölçümlemişlerdir. Yalnızca web sitesi kompleksitesi değişkeni kullanıldığında uyumun hızlı bir şekilde gerçekleştiğini ancak diğer değişkenler ele alındığında uyumun ciddi derecede düştüğü bulgularına ulaşmışlardır.

Damanpour ve Schneider (2009) kamu kuruluşlarında inovasyon özellikleri, yönetici özellikleri ve inovasyonu benimseme arasındaki ilişkiyi incelemek için Amerika Birleşik Devletleri'ndeki 725 yerel yönetimde 25 yeniliğin benimsenmesine ilişkin anket verilerini kullanmışlardır. Bulgular hem inovasyon özelliklerinin hem de yönetici özelliklerinin yeniliğin benimsenmesini etkilediğini ancak yönetici özelliklerinin inovasyon özellikleri ile inovasyonun benimsenmesi arasındaki ilişki üzerinde anlamlı etkisinin olmadığg sonucuna ulaşmışlardır.

Gallagher ve Muehlegger (2011) hibrit araç satışlarının vergi teşviklerine ve benzin fiyatlarına olan tepkisini ölçmüşlerdir. Elde ettikleri ampirik bulgular federal, eyalet ve yerel yönetimler düzeylerinde eyalet satış vergisi muafiyetlerinin, gelir vergisi kredilerinin ve vergi dışı teşviklerin göreceli etkinliğinin olduğunu destekleyen sonuçlar sunmuştur.

Betsill (2004) çalışmasında uluslararası ilişkiler akademisyenleri arasında ve özellikle de küresel çevre yönetişimi literatürüne katkı verenlerde ulus ötesi ağların rolünün giderek arttığı belirtmiştir. $\mathrm{Bu}$ ağlardan birisi olan ve iklim değişikliğinin azaltılmasına yönelik yerel girişimleri teşvik etmekle ilgilenen yaklaşık 550 yerel yönetimden oluşan İklim Koruma Şehirleri (Cities for Climate Protection) programına odaklanmıştır. Çalışmanın soncunda ulus ötesi ağların küresel çevre yönetişimindeki potansiyel önemi belgelenmiş olsa da etkileri hakkında birçok sorunun devam ettiğini belirtmiştir.

Black ve Henderson (1999) kentleşmenin büyüme verimliliği üzerindeki etkisi ve büyümenin kentleşme üzerindeki etkisini araştırmıştır. Kentleşmenin büyüme üzerindeki etkisi açısından, teorik 
olarak, kentsel kurumların yerel bilgi yayılımlarının içselleştirilmesiyle verimli büyümeye yol açabileceğini ancak uygulamanın önemli sorunlarla karşı karşıya oldukları; kentleşmenin eşitsizlik üzerindeki etkisi hakkında ise tüketim farklılıkları olmasa da şehirler arasında nominal ve reel gelir eşitsizliği ölçüldüğü sonucuna ulaşmışlardır.

Devereux vd. (2008) OECD ülkelerinin kurumlar vergisi üzerinden rekabet düzeyini araştırmıştır. Çok uluslu şirketlere uygulamam efektif marjinal vergi oranı veri olarak alınarak bir model geliştirmiştir. Analizin sonucunda ülkelerin birbirilerini etkileyerek kurumlar vergisi oranlarını revize ettiği sonucuna ulaşmışladır.

Coursey ve Norris (2008) e-devlet hizmetlerinin gelişimini ve yararlılık derecesini anlamak için Amerika Birleşik Devletleri'ndeki üç yerel yönetimin e-devlet hizmetleri üzerinden ampirik bir çalışma gerçekleştirmişlerdir. Çalışmanın sonucunda e-devlet hizmetlerinin çoğunlukla bilgilendirici olduğunu ve az sayıda uygulamaya yönelik işlem yapılabildiği sonucuna ulaşmışlardır.

Seabright (1996) iş akdi tamamlanmayan sözleşmeler kapsamında kontrol haklarının yönetim düzeyleri arasında tahsis edilmesi konusunu araştırmıştır. Kurulan modelde yerel, merkezi ve bölgesel yönetimlere güç tahsisini, yönetimleri vatandaşların çıkarları doğrultusunda hareket etmeye motive etmek için alternatif bir araç olarak karşılaştırmaktadır. Çalışmanın sonucunda merkezileşmenin politika koordinasyonu açısından fayda sağladığı ancak topluma hesap verebilirlik açısından maliyetleri olduğu kanısına varmıştır.

Pierre (1999) Batı Avrupa'daki yerel yönetimlerin, yerel iş dünyasıyla ağ oluşturma konusunda giderek daha fazla yer aldığını belirtmiştir. Bu ağ oluşurken gözlemlenen yönetişim süreçlerinin tarafsız bir değer olmadığını, partizan çatışmasının ötesinde siyasi değerleri yansıttığını öne sürmüştür. Kentsel yönetişimin yönetsel, sermaye odaklı ilerleme ve refah yönetişim modellerini karşılaştıran yazar, ulus-devlet faktörlerinin kentsel yönetişimin şekillendirilmesinde önemli bir rol oynadığını savunmuştur.

Amundsen vd. (2010) tüm Norveç Belediyelerine gönderilen iki anketin sonuçlarını analiz ettiği çalışmasında; yerel yönetimler tarafından alınan küresel iklim değişikliğine uyum önlemlerine genel bir bakış sunmuştur. Analizlerinde belediyelerin aşırı yağış ve sel ile ilgili önlemlere, binaların ve altyapının iklim değişikliğine karşı güvence altına alınmasına yönelik önlemlerden daha fazla yatırım yaptığını göstermiştir.

Brueckner ve Saavedra (2001) yerel yönetimler arasında emlak vergisi rekabetini araştırmak için mekânsal ekonometrik yöntemler kullanmışladır. Teorik model vergi farklılıklarına yanıt olarak mobil sermayenin göçünü dikkate alarak emlak vergisi oranlarının belirlendiği vergi rekabeti literatüründen alınmıştır. Boston Metropol bölgesindeki 70 şehir için gerçekleştirilen analiz sonucunda; emlak vergisi ve diğer sosyo-ekonomik değişkenler doğrultusunda mükelleflerin stratejik olarak etkileşim içerisinde olduğu sonucuna ulaşmışlardır.

Schneider ve Teske (1992) girişimciliğin ekonomik yaklaşım yönleri ile siyaset biliminde kullanılan kavramları sentezlemeye çalışmıştır. Elde ettiği teorik gözlemleri yerel yönetimlerde girişimcilerin ortaya çıkmasıyla ilişkilendirmiş ve belediye yönetimlerinin gözlemlerini kullanarak test etmişlerdir.

Wheeler (2008) Amerika Birleşik Devletleri'nde eyalet ve yerel yönetimlerin küresel iklim değişikliğine karşı planlama süreçlerini ele aldığ çalışmasında iklim değişikliği ile ilgili planlama belgelerine sahip tüm eyaletler, 500.000'den fazla nüfusa sahip şehirler ve küçük şehirleri örneklem olarak kullanmıştır. Wheeler çalışmanın sonucunda planların çoğunun emisyon azaltma hedeflerini belirlediği, emisyon envanterleri oluşturduğu ve 2050 yılında sera gaz salınımını 2000 yılına göre $\% 80$ azaltmak, bu hedefe yönelik ilerlemeyi dinamik bir şekilde izleyen ve gerektiğinde planlanan eylemleri revize eden uzun vadeli bir planlama çerçevesi kullanımı, mobilite ihtiyacının azaltılması, toplu taşımanın verimliliğinin artırılması, bina enerji verimliliğini günümüz kanunlarının ötesinde iyileştirilmesi gibi bir dizi başka önlemler reçetesi önermiştir.

Tao vd. (2010), Cin'in geçiș sürecindeki farklı dönemlerinde yerel yönetimlerin rollerinin evrimini analiz etmektedir. Çalışmada 1990'ların ortasından itibaren üretim yatırımı için bölgesel rekabette kilit araçlar olarak kullanmaya yönelik yerel mali teşvikleri olan devlet destekli arazi ve 
altyap1 araştırılmaktadır. 1999'dan 2003'e kadar vilayetleri kapsayan panel verilerine dayanarak çalışma, farklı arazi kiralama biçimlerinin mali etkilerini deneysel olarak analiz etmektedir. Çin'in kentsel arazi sistemi ve mali kurumlarında reform çalışmaları için politika tavsiyelerinde de bulunulmuştur.

Blanchard ve Shleifer'ın (2000) politik merkezileşme ve merkezileşme olmadan federalizm teorisini Rusya ve Çin örnekleri üzerinden tartıştıkları çalışmalarında; Çin'de, yerel yönetimler yeni firmaların büyümesine aktif olarak katkıda bulunduğunu ancak Rusya'da, yerel yönetimler genellikle vergilendirme, regülasyonlar veya yolsuzluk yoluyla firmaların büyümesini engelledikleri bulgularına ulaşmışlarıdır. Bu durumun temel sebebinin Çin'de komünist partinin çok güçlü bir şekilde yerel yönetimler üzerinde etkisinin olmasına ve büyümeyi desteklemesine; Rusya'da ise bu bağın güçlü olmaması sebebi ile yerel yönetimlerin bireysel çıkarların maksimizasyonu yönünde karar almaları olduğunu öne sürmüşlerdir.

\section{SONUÇ}

Çalışmada kamu yönetimi ve maliye alanlarını birleştiren, interdisipliner bir alan olan yerel yönetimler ve bütçe ilişkisi incelenmiştir. İncelemede makro bir bakış açısı sunulabilmesi için ilgili literatüre ait makaleler bibliyometrik analizle haritalandırılmış ve literatürde önemli yere sahip olan çalışmalar ayrıntılı değerlendirilmiştir.

VOSviewer programı aracılığıyla yapılan bibliyometrik haritalamada karşımıza çıkan en önemli bulgu ilgili literatürün hem en etkili yazarlarına hem de kurumlarına ev sahipliği yapan devletin Amerika Birleşik Devletleri olduğudur. ABD adresli yazarlar hem alınan atıf sayıları hem de kurdukları iş birlikleri ile genellikle ağların merkezinde yer almışlardır. Aynı zamanda ABD kurumları da yazar analizinde olduğu gibi hem atıf hem de etki faktörü bakımından ağların merkezinde yer almayı başarmıştır. Anahtar kelimeler açısından ilgili literatür incelendiğinde ise çalışmaların çoğunluğunun ekonomi ve kamu yönetimi alanları ile ilgili olmak üzere çeşitlendiği saptanmıştır. Anahtar kelimelerde en etkin ikinci terim ise Çin olmuştur. En fazla atıf alan çalışmalarda da Çin'i konu alan çalışmaların göreceli olarak daha fazla yer aldığı belirlenmiştir.

Çalışmanın bibliyometrik analizinin ardından ilgili literatürde en çok atıf alan çalışmalara yer verilmiştir. İkinci aşamada detaylı incelemenin temel sebebi literatürün yoğunlaştığı alanları tespit etmektir. En çok atıf alan makalelere genel olarak bakıldığında, sosyalist ekonomiden kapitalist piyasaya açılan geçiş sürecindeki Çin'in en çok atıf alan makalelerde ciddi yer tuttuğu gözlemlenmiştir. Atıf açısından güçlü bağlantıya sahip yayınların yayımlandığı dergiler incelendiğinde; Public Administration Review dergisinin literatürde önemli bir yere sahip olduğu görülmüştür. Ekonomik kalkınmada sanayileşmenin motoru olarak görülen yerel yönetimlere sağlanan geniş mali desantralizasyon teşvikleri, bölgesel kalkınmanın piyasalarda yarattığı dengesizlikler, mülkiyet hakkına dayanmaksızın sistemin işleyebilmesi bakımından Batı'nın bilindik kuramlarını sarsması bu makalelerin vurguladıkları hususlardır. Aynı zamanda örgüt ve yönetim düzeyinde performans konusunun en çok atıf alan çalışmalarda yer aldığı görülmektedir. Ayrıca kamu yönetimi açısından afet ve kriz yönetimi ile e-devlet uygulamaları çalışılmıştır. ABD özelinde ise mali federalizm kuram ve konusunun işlendiği tespit edilmiştir.

Araştırmanın sınırlılığı olarak, makale veri tabanı oluşturulurken kullanılan outlier parametreleri ve WoS çekirdek katalog içerisindeki yayınların kullanılmasıdır. Bu parametrelerinin kullanılmasının temel sebebi alanı dışı dergi ve çalışmaların analizlerden çıkarılmasıdır. Çalışmada kullanılan outlier parametrelerinin genişletilmesi ve WoS çekirdek kataloğundan farklı veri tabanlarının kullanılması çeşitli alanları kapsayacaktır. Aynı zamanda interdisipliner düzeyi artıracak çalışmaların analizine katkıda bulunacaktır. Ayrıca alanda Public Administration Review gibi önemli dergilerin içerik analizlerinin haritalanması da literatürdeki güncel eğilimleri takip etmek açısından önemli göstergeler sunacağı düşünülmektedir. 
Etik Beyanı: Bu çalı̧̧mada "Etik Kurul” izni gerektiren bir yöntem kullanılmamıştır.

Yazar Katkı Beyanı:1. Yazarın katkı oranı \%50, 2. Yazarın katkı oranı ise\%50'dir.

Çıkar Beyanı: Yazarlar arasında çıkar çatışması yoktur.

Ethic Statement: In this study, no method requiring the permission of the "Ethics Committee" was used.

Author Contributions Statement: 1st author's contribution rate 50\%, 2nd author's contribution rate $50 \%$.

Conflict of Interest: There is no conflict of interest among the authors.

\section{KAYNAKÇA}

Amundsen, H., Berglund, F., \& Westskog, H. (2010). Overcoming barriers to climate change adaptation question of multilevel governance?. Environment and Planning C: Government and Policy, 28, 276-289. http:// doi.org/10.1068/c0941

Arıkboğa, E. (2008). Yerel yönetimler ve organları: Organlararası ilişkilerin üç boyutlu analizi. R. Bozlağan, \& Y. Demirkaya (Ed.), Türkiye'de yerel yönetimler (ss. 157-204). Nobel Yayın \& Dağıtım.

Arıkboğa, Ü. (2008). Yerel yönetimlerin gelir kaynakları. R. Bozlağan, \& Y. Demirkaya (Ed.), Türkiye'de yerel yönetimler (ss. 251-286). Nobel Yayın \& Dağıtım.

Artsın, M. (2020). Bir metin madenciliği uygulaması: VosViewer. Eskişehir Teknik Üniversitesi Bilim ve Teknoloji Dergisi, 8(2), 344-354. http://doi.10.20290/estubtdb.644637

Behn, R. D. (2003). Why measure performance? Different Purposes require different measures. Public Administration Review, 63(5), 586-606. http://doi: 10.1111/1540-6210.00322

Betsill, M. M. (2004). Transnational networks and global environmental governance: The cities for climate protection program. International Studies Quarterly, 48, 471-493. https://doi.org/10.1111/j.0020-8833.2004.00310.x

Black, D., \& Henderson, V. (1999). A theory of urban growth. Journal of Political Economy, 107(2), 252-284. http:// dx.doi.org/10.1086/250060

Blanchard, O. \& Shleifer, A. (2000). Federalism with and without political centralization: China versus Russia. Cambridge. http://www.nber.org/papers/w7616

Boyack, K. W., Klavans, R., \& Börner, K. (2005). Mapping the backbone of science. Scientometrics, 64(3), 351-374. http:// 10.1007 / s11192-005-0255-6

Brueckner, J. K. (2003). Strategic interaction among governments: An overview of empirical studies. International Regional Science Review, 26(2), 175-188. http://10.1177/0160017602250974

Brueckner, J. K., \& Saavedra, L. A. (2001). Do local governments engage in strategic property-tax competition?. National Tax Journal, 54(2), 203-229. http:////doi.org/10.17310/ntj.2001.2.02

Bulkeley, H., \& Betsill, M. M. (2005). Rethinking sustainable cities: Multilevel governance and the "urban" politics of climate change. Environmental Politics, 14(1), 42-63. http://10.1080/0964401042000310178

Burby, R. J. (2006). Hurricane Katrina and the paradoxes of government disaster policy: Bringing about wise governmental decisions for Hazardous Areas. The ANNALS of the American Academy of Political and Social Science, 604(1), 171-191. http://10.1177/0002716205284676

Coursey, D., \& Norris, D. F. (2008). Models of e-government: Are they correct? An empirical assessment. Public Administration Review, 68(3), 523-536. https://doi.org/10.1111/j.1540$\underline{6210.2008 .00888 . \mathrm{x}}$

Çelikkaya, S., \& Atila, M. (2020). Göç ve kalkınma ilişkisine yönelik bir inceleme: Web of Science veri tabanına dayalı bibliyometrik ağ analizi. Karadeniz Sosyal Bilimler Dergisi, 12(23), 67-85. http: //doi.org/10.38155/ksbd.797055 
Damanpour, F., \& Schneider, M. (2009). Characteristics of innovation and innovation adoption in public organizations: Assessing the role of managers. Journal of Public Administration Research and Theory, 19(3), 495-522. http://10.1093 / jopart / mun021

De, D., \& Price, S. (1976). A General theory of bibliometric and other cumulative advantage processes. Journal of the American Society for Information Science, September-October. https://www.imsc.res.in/ sitabhra/teaching/sb17/Price 1976 A general theory of bibliometric and other cumulative advantage processes.pdf

De Lancer Julnes, P., \& Holzer, M. (2001). Promoting the utilization of performance measures in public organizations: An empirical study of factors affecting adoption and implementation. Public Administration Review, 61(6), 693-708. http://10.1111/0033-3352.00140

Delen, D., \& Crossland, M. D. (2008). Seeding the survey and analysis of research literature with text mining. Expert Systems with Applications, 34(3), 1707-1720. https://doi.org/10.1016/j.eswa.2007.01.035

Devereux, M. P., Lockwood, B., \& Redoano, M. (2008). Do countries compete over corporate tax rates?. Journal of Public Economics, 92(5-6), 1210-1235. http://10.1016/j.jpubeco.2007.09.005

Eryılmaz, B. (2019). Кати yönetimi düşünceler yapılar fonksiyonlar politikalar. Umuttepe.

Gallagher, K. S., \& Muehlegger, E. (2011). Giving green to get green? Incentives and consumer adoption of hybrid vehicle technology. Journal of Environmental Economics and Management, 61(1), 1-15. http://www.sciencedirect.com/science/article/pii/S0095-0696(10)00076-8

Gürdin, B. (2020). Yeşil pazarlamanın bilimsel haritaların görselleştirilmesi tekniğiyle bibliyometrik analizi. Econder International Academic Journal, 4(1), 203-231. https://doi.org/10.35342/econder.738473

Ho, A. T. K. (2002). Reinventing local governments and the e-government initiative. Public Administration Review, 62(4), 434-444. http://10.1111/0033-3352.00197

Jin, H., Qian, Y., \& Weingast, B. R. (2005). Regional decentralization and fiscal incentives: Federalism, Chinese style. Journal of public economics, 89(9), 1719-1742. http://www.sciencedirect.com/science/article/pii/S0047-2727(05)00022-8

Kessler, M. M. (1963). Bibliographic coupling between scientific papers. American Documentation, 14(1), 10-25. http://10.1002/asi.5090140103

Klavans, R., \& Boyack, K. W. (2006). Quantitative evaluation of large maps of science. Scientometrics, 68(3), 475-499. https://doi.org/10.1007/s11192-006-0125-X

Leydesdorff, L., \& Rafols, I. (2009). A global map of science based on the ISI subject categories. Journal of the American Society for Information Science and Technology, 60(2), 348-362. https://doi.org/10.1002/asi.20967

Montinola, G., Qian, Y., \& Weingast, B. R. (1995). Federalism, Chinese style: The political basis for economic success in China. World Politics, 48(1), 50-81. http://10.7551/mitpress/9780262534246.003.0008

Morris, S., DeYong, C., Wu, Z., Salman, S., \& Yemenu, D. (2002). Diva: A visualization system for exploring document databases for technology forecasting. Computers \& Industrial Engineering, 43(4), 841-862. https://doi.org/10.1016/S0360-8352(02)00143-2

Norris, D. F., \& Moon, M. J. (2005). Advancing e-government at the grassroots: Tortoise or hare?. Public Administration Review, 65(1), 64-75. https://doi.org/10.1111/j.1540-6210.2005.00431.x

Oates, W. E. (1999). An essay on fiscal federalism. Journal of Economic Literature, 37(3), 1120-1149. http://www.jstor.org/stable/2564874

Oates, W. E. (2005). Toward a second-generation theory of fiscal federalism. International Tax and Public Finance, 12(4), 349-373. http://10.1007/s10797-005-1619-9 
Oi, J. C. (1992). Fiscal reform and the economic foundations of local state corporatism in China. World Politics, 45(1), 99-126. https://doi.org/10.2307/2010520

Pierre, J. (1999). Models of urban governance the institutional dimension of urban politics. Urban Affairs Review, 34(3), 372-396. https://doi.org/10.1177/10780879922183988

Qian, B. Y., \& Roland, G. (1998). Federalism and the soft budget constraint. The American Economic Review, $88(5)$,

1143-1162. https://www.jstor.org/stable/116864?seq=1\#metadata info tab contents

Scherf, M., Epple, A., \& Werner, T. (2005). The next generation of literature analysis: Integration of genomic analysis into text mining. Briefings in Bioinformatics, 6(3), 287-297. http://10.1093/bib/6.3.287

Schneider, M., \& Teske, P. (1992). Toward a theory of the political entrepreneur: Evidence from local government. The American Political Science Review, 86(3), 737-747. https://doi.org/10.2307/1964135

Seabright, P. (1996). Accountability and decentralisation in government: An incomplete contracts model. European Economic Review, 40, 61-89. http://www.sciencedirect.com/science/article/pii/0014-2921(95)00055-0

Small, H., \& Sweeney, E. (1985). Clustering the Science Citation Index ${ }^{\circledR}$ using co-citations. Scientometrics, 7(3), 391-409. https://doi.org/10.1007/BF02017157.

Small, H., Sweeney, E., \& Greenlee, E. (1985). Clustering the science Citation Index using co-citations. II. Papping science. Scientometrics, 8(5-6), 321-340. https://doi.org/10.1007/BF02018057.

Tabak, A., Barbak, A., \& Öztürk, T. (2016). Kamu politikası disiplininin kavramsal gelişimini bibliyometri kullanarak anlamak mümkün mü?: 1980-2014 döneminin bilimsel haritalama analizi. LAÜ Sosyal Bilimler Dergisi, 7(2), 117-143. https://dergipark.org.tr/tr/download/article$\underline{\text { file/263055 }}$

Tao, R., Su, F., Liu, M., \& Cao, G. (2010). Land leasing and local public finance in China's regional development: Evidence from prefecture-level cities. Urban Studies, 47(10), 2217-2236. https://doi.org/10.1177/0042098009357961

Tolbert, C., \& Mossberger, K. (2006). The effects of e-government on trust and confidence in government. Public Administration Review, 66(3), 354-369. https://doi.org/10.1111/j.15406210.2006.00594.X

Ulusoy, A., \& Akdemir, T. (2009). Yerel yönetimler ve mali özerklik: Türkiye ve OECD ülkelerinin karşılaştırmalı analizi. Balıkesir Üniversitesi Sosyal Bilimler Enstitüsü Dergisi, 12(21), 259-287. https://dergipark.org.tr/tr/download/article-file/857114

Van Eck, N. J., \& Waltman, L. (2010). Software survey: VOSviewer, a computer program for bibliometric mapping. Scientometrics, 84(2), 523-538. http://10.1007/s11192-009-0146-3

Van Eck, N. J., \& Waltman, L. (2016). Text mining and visualization. Text Mining and Visualization, 1-5. http://10.1201/b19007

Waltman, L., van Eck, N. J., \& Noyons, E. C. M. (2010). A unified approach to mapping and clustering of bibliometric networks. Journal of Informetrics, 4(4), 629-635. http://10.1016/j.joi.2010.07.002

Wheeler, S. M. (2008). State and municipal climate change plans: The first generation. Journal of the American Planning Association, 74(4), 481-496. https://doi.org/10.1080/01944360802377973

White, H. D., \& Griffith, B. C. (1981). Author cocitation: A literature measure of intellectual structure. Journal of the American Society for information Science, 32(3), 163-171. http://garfield.library.upenn.edu/hwhite/whitejasist1981.pdf

Yenice, E. (2006). Kamu kesiminde performans ölçümü ve bütçe ilişkisi. Saylştay Dergisi, 61, 57-68. https://doi.org/10.17218/husbed.39085 
Young, A. (2000). The Razor's edge: Distortions and incremental reform in the people's Republic of China. Quarterly Journal of Economics, CXV(4), 1091-1135. https://www.jstor.org/stable/2586920

Zhang, T., \& Zou, H. (1998). Fiscal decentralization, public spending, and economic growth in China. $\begin{array}{llll}\text { Journal of Public } & \text { Economics, } 21-240 .\end{array}$ http://www.sciencedirect.com/science/article/pii/S0047-2727(97)00057-1 